Proc. Estonian Acad. Sci. Geol., 1997, 46, 4, 187-196

\title{
HYDROXYAPATITE VARIETIES IN RECENT FISH SCALES
}

\author{
Jüri NEMLIHER ${ }^{\mathrm{a}, \mathrm{b}}$, Toivo KALLASTE ${ }^{\mathrm{a}}$, and Ivar PUURA $^{\mathrm{a}}$
}

a Institute of Geology, Estonia pst. 7, EE-0001 Tallinn, Estonia; e-mail: nemliher@gi.ee; ipuura@math.ut.ee

b Institute of Geology, University of Tartu, Vanemuise 46, EE-2400 Tartu, Estonia

Received 27 August 1997, in revised form 1 October 1997

\begin{abstract}
Mineralogy of apatite in the scales of Recent sharks, rays, and teleosts was studied using $\mathrm{X}$-ray diffraction analysis. All the studied fish scales are composed of hydroxyapatite with different lattice parameters. The apatite in the scales of Recent rays and teleosts has lattice parameters within the range of $a=9.44-9.46$ and $c=6.87-6.88$, which is comparable to the apatite in Recent vertebrate bones. The shark scale apatite has lattice parameters $a=9.40-9.41$ and $c=6.87-6.88$, closer to the apatite in Recent lingulate brachiopod shells. The distinct lattice parameters reflect differences in the chemical composition, first of all, in the content of hydroxyl, fluorine, and carbonate anions. These differences between the higher taxa of Recent fishes are significant from an evolutionary perspective and have implications to the interpretation of the mineralogy of fossil vertebrate skeletons.
\end{abstract}

Key words: X-ray diffraction, hydroxyapatite, fishes, biomineralization.

\section{INTRODUCTION}

Hydroxyapatite occurs in hard tissues, e.g., bones and teeth of all Recent vertebrates (Carter, 1990). Early vertebrates, e.g., Early Palaeozoic and Devonian fishes, had a dermal skeleton composed of apatite (Ivanov et al., 1992; Nemliher et al., 1996). The homology to dermal sclerites of early vertebrates makes the study of Recent fish scales intriguing from an evolutionary perspective and significant for interpreting the mineral composition of fossil fish fragments.

In invertebrates, hydroxyapatite is a well-known compound of a chitinophosphatic shell of lingulate brachiopods, such as Recent Lingula, Glottidia, and Discinisca (LeGeros et al., 1985; Watabe, 1990; Nemliher \& Puura, 1996). Lowenstam \& Weiner (1992) reported a hard apatitic tissue in plates of the barnacle genus Ibla, but its precise mineral composition remains unknown. 
In spite of many previous X-ray diffraction (XRD) studies of apatite in vertebrate tissues, to our knowledge, methodologically consistent comparative analyses of hydroxyapatite varieties in higher vertebrate taxa are very rare. The present investigation was initiated as an integral part of our research on skeletal apatite of fossil fishes from the Devonian of Estonia (Nemliher et al., 1996), to provide comparative Recent data for interpreting complex mineralogies of fossil dermal skeletons. Our task was to compare apatite mineralogy in scales of higher taxa of Recent fishes, including sharks, rays, and teleosts by evaluating the variation range of lattice parameters, crystallite dimensions, and habitus.

\section{MATERIAL}

The material studied includes scales of sharks, rays, and teleosts; lingulate brachiopod shells, a cow bone, and a human tooth were studied for comparison (Table 1). Scales and bones of Recent sharks and rays were kindly given for

The studied material

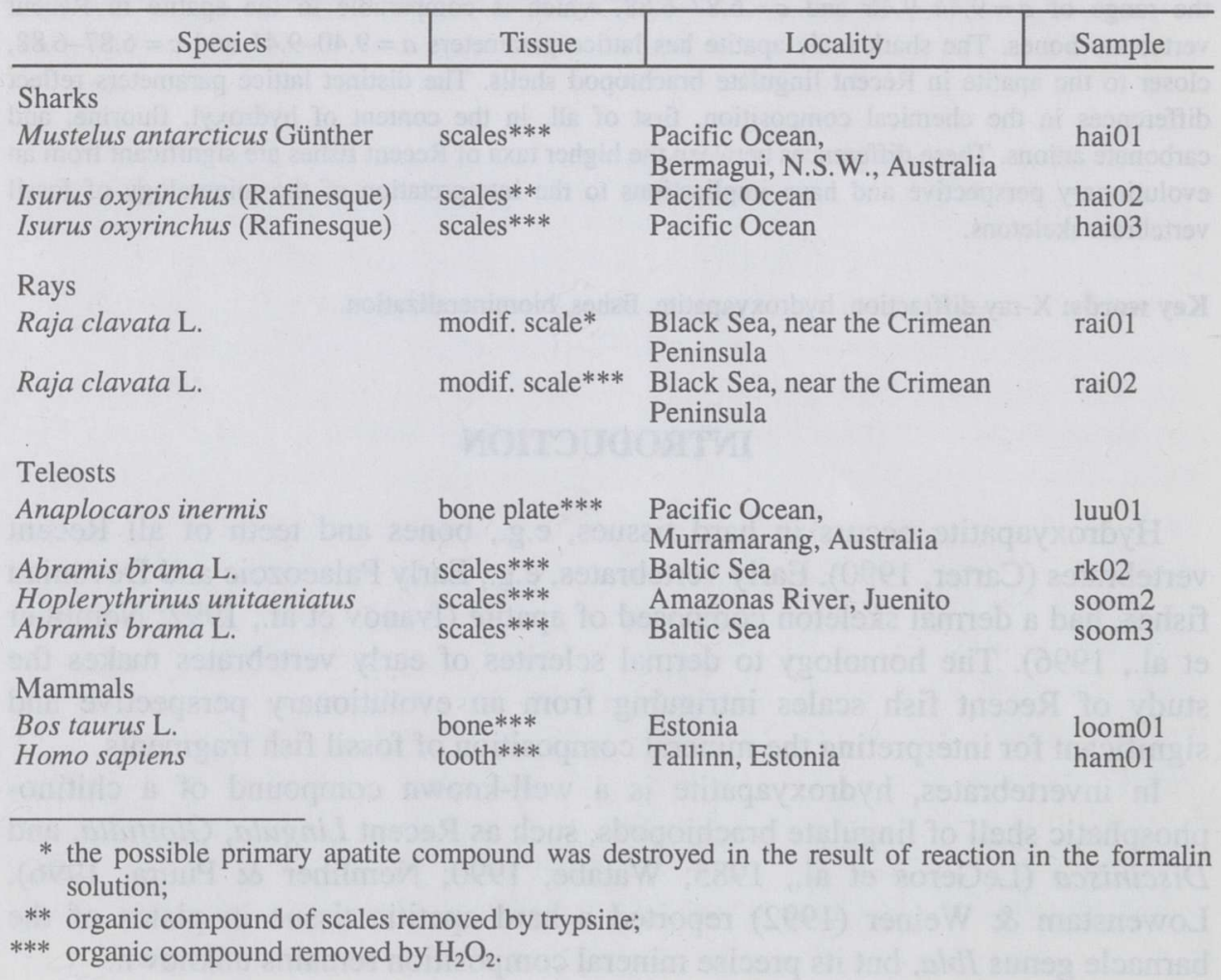


study by Dr. Peter Pridmore (Australian National University), Dr. Elga Kurik (Institute of Geology, Tallinn), and Dr. Peeter Ernits (Natural History Museum of Estonia). Air-dried samples of the Recent lingulate brachiopod Lingula anatina from the Philippines were provided by Dr. Enrico Savazzi (Uppsala University). The studied human tooth was donated for this study by Sten Kallaste. The analysed cow bone was extracted from a commercially obtained piece of beef.

\section{METHODS}

\section{Sample preparation and XRD analysis}

Room-dry scales and other hard parts of studied objects were boiled in concentrated $\mathrm{H}_{2} \mathrm{O}_{2}$ during $10-15$ min. As a result their organic component was oxidized. From one sample (hai02), the organic component was earlier removed by trypsine. The processing residue was powdered in a mortar, about $5-10 \%$ of pure quartz (angle correction standard) was added, mixed with some drops of alcohol and spread on a glass as a patch $30-35 \mathrm{~mm}$ in diameter. The samples were scanned in a step scan mode, with a step of $0.02^{\circ}$ within the $2 \Theta$ range of $29-41^{\circ}$ and $54-64^{\circ}$. These intervals included 16 apatite and two quartz reflections. Fe-filtered Co radiation was used. The studied apatite XRD reflections included $002,102,210,211,112,300$, and 202 (first group), and 222, $321,312,213,410,402$, and 004 (second group). The least-squares' fitting was applied for processing the measurement results, using a general-purpose software. An example of the XRD pattern for both measured ranges with fitted curves is shown in Fig. $1 a$ and $b$. From the fitted XRD data, lattice parameters were calculated. Fitted half-widths of apatite peaks were used for interpretation of crystallinity.

\section{Processing and interpretation of the XRD data}

\section{Lattice parameters}

The XRD patterns were corrected for apparatus-related peak position shift and peak widening against the peaks of quartz, added as an internal standard. The apatite lattice parameters, $a$ and $c$, were calculated by the least-squares' method using the positions of peaks as input data, with the precision allowing us to distinguish between different apatite varieties.

\section{Crystallinity}

Parameters characterizing the size and habitus of a crystallite were calculated from half-widths of the fitted peak profiles. The peak profiles were fitted using Lorenzian and Cauchy distributions and their combination. 

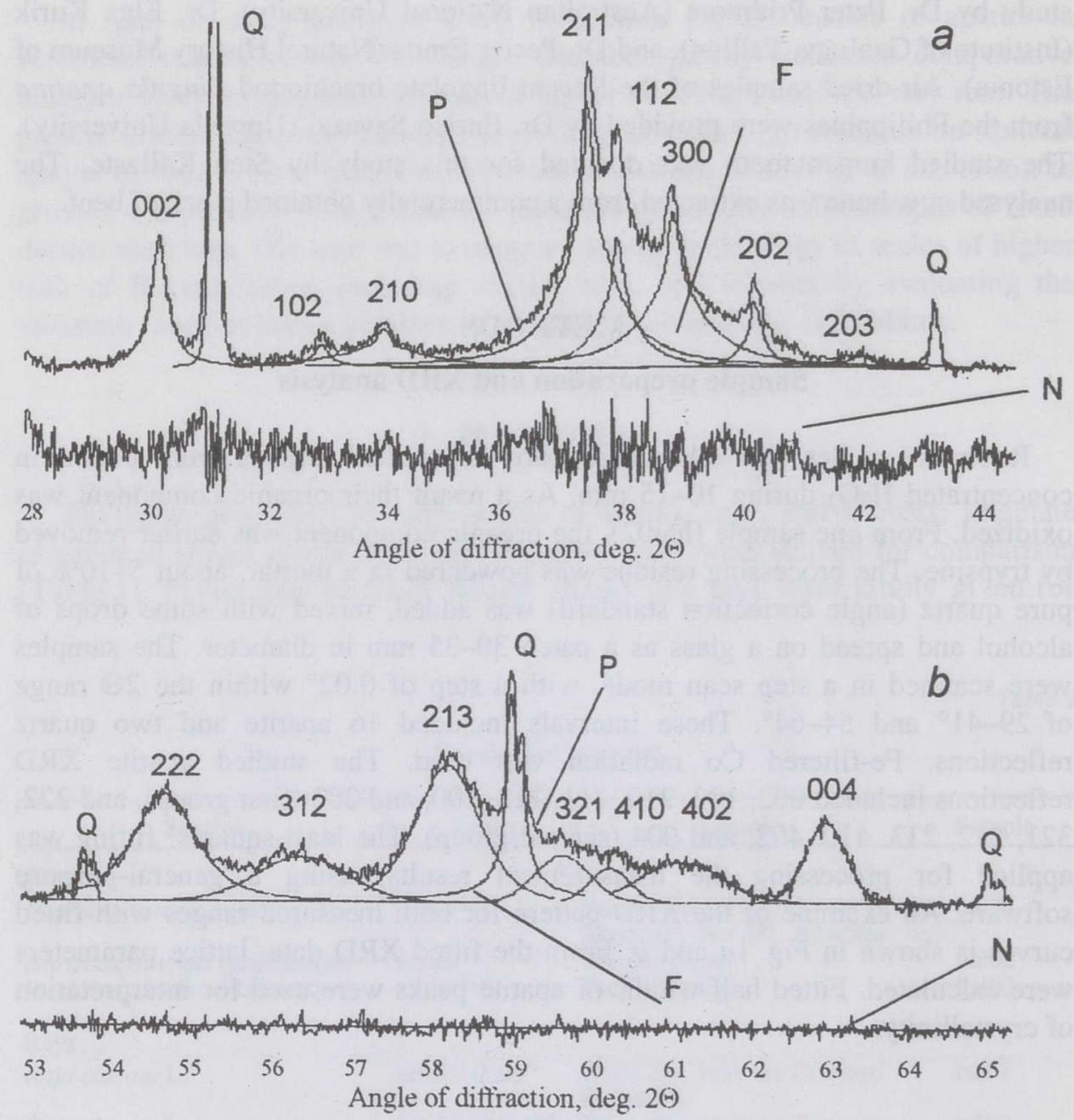

Fig. 1. The apatite XRD patterns of Recent fish scales. $a$, a shark Isurus oxyrinchus (sample hai02) in $2 \Theta$ range of $29-41^{\circ} ; b$, a teleost, perch Abramis brama (sample soom3) in $2 \Theta$ range of $54-64^{\circ}$. $\mathrm{Q}$, quartz peaks (added internal standard). The measured profile is marked by $\mathrm{P}$, the fitted functions by $\mathrm{F}$, and the their difference in each point by $\mathrm{N}$.

According to the theory of X-ray diffraction, the peak widths and profile shapes are caused by two factors: dimensions of elementary crystallites and degree of homogeneity. The first factor can be detected when the crystals are smaller than $1000 \AA$. The second factor is related to heterogeneity of monocrystal 
blocks, i.e., if a crystal contains parts or zones with different lattice parameters and/or strains. These two factors can be distinguished by comparing the peak widths of the same orientation (e.g., 001, 002, etc.) at different angles. Namely, the dependence of reflection widening on the diffraction angle is different for the two factors discussed above. The most informative part of an XRD pattern for estimating the heterogeneity of crystallites is the range of lower angles, i.e., the first group of apatite reflections. As each reflection corresponds to a definite lattice direction, it is possible to make a semiquantitative estimation of average crystallite dimensions in lattice directions [001] (alongside hexagonal prism) and [hk0] (alongside pinacoidal plane).

\section{RESULTS}

\section{Lattice parameters}

As the chemical composition of biogenic apatites is rather variable, conventional mineral names, e.g., francolite or dahllite, express very roughly the composition of an apatite variety. A much closer approximation can be given by lattice parameters which reflect a complex function of ionic radii in apatite lattice characterizing the chemical composition of each particular apatite variety (McConnell, 1973; Hughes et al., 1989).

For discussing apatite crystallography, pure fluorapatite is usually considered as the prototype of the apatite family (e.g., Nathan, 1984). Crystallographically, pure F-apatite belongs to hexagonal syngony. The F-apatite lattice can be described by a unit cell, having a shape of a prism with rhomboidal base. This unit cell can be characterized by two lattice parameters, $a$ (margin of the base) and $c$ (height). In case of F-apatite, the approximate values are $a=9.37 \AA$ and $c=6.88 \AA$ (McConnell, 1973). Pure F-apatite can be obtained synthetically, but it occurs seldom in nature, and is not reported to be formed biogenically (Carter, 1990).

The apatite varieties occurring in Recent vertebrate and invertebrate skeletons are known to be within the range of carbonate-hydroxyapatites (Carter, 1990). This rather variable group of apatites is conventionally called dahllite. As compared to the lattice of pure fluorapatite, part of the positions of the $\mathrm{F}$ anion is occupied by the $\mathrm{OH}$ anion, and the lattice parameter $a$ usually ranges from 9.40 to $9.45 \AA$ (Brophy \& Nash, 1968; Miller, 1984). Most of the studied samples (Table 2; Fig. 2) fall within this range. Differences in the lattice parameters of skeletal apatites reflect mostly variations in the content of $\mathrm{OH}^{-}$ and $\mathrm{CO}_{3}{ }^{2-}$. 


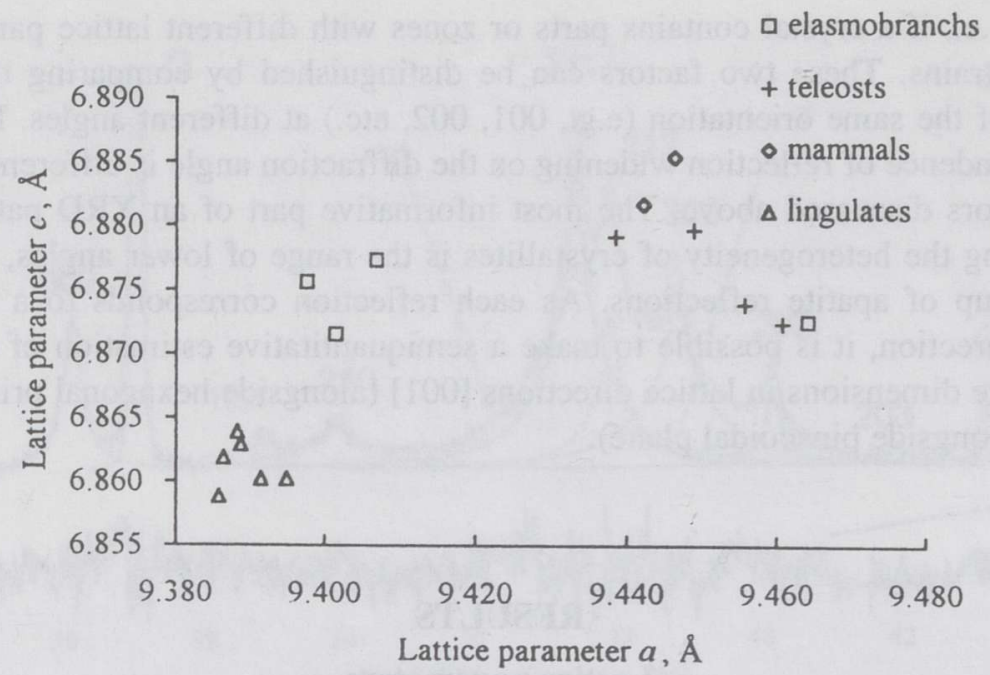

Fig. 2. Scatter plot of apatite lattice parameters $a$ vs $c$ from hard tissues of studied Recent vertebrates and lingulate brachiopods.

Table 2

Lattice parameters of the studied apatites. The precision of values calculated for vertebrate material is lower due to combination of peak positions and crystallinity

\begin{tabular}{lllll}
\hline \multicolumn{1}{c|}{ Species } & $a, \AA$ & $c, \AA$ & Sample \\
\hline Sharks & & & \\
Isurus oxyrinchus & 9.402 & 6.872 & hai02 \\
$\begin{array}{l}\text { Isurus oxyrinchus } \\
\text { Mustelus antarcticus }\end{array}$ & 9.398 & 6.876 & hai03 \\
Ray & 9.407 & 6.877 & hai01 \\
Raja clavata & & & \\
Teleosts & 9.464 & 6.873 & rai02 \\
Abramis brama & & & \\
Abramis brama & & & \\
Hoplerythrinus unitaeniatus & 9.456 & 6.874 & soom3 \\
Anaplocaros inermis & 9.461 & 6.872 & rk02 \\
Lingulate brachiopods & 9.449 & 6.879 & luu01 \\
Lingula anatina & & 6.880 & \\
Lingula anatina & & & BRF03 \\
Lingula anatina & $9.386(4)$ & $6.861(9)$ & BRF04 \\
Lingula anatina & $9.388(3)$ & $6.863(9)$ & BRF07i \\
Lingula anatina & $9.391(5)$ & $6.859(1)$ & BRF07o \\
Mammals & $9.387(0)$ & $6.863(1)$ & BRF20 \\
Bos taurus & $9.391(2)$ & $6.861(7)$ & \\
Homo sapiens & & & loom01 \\
& 9.442 & 6.882 & ham01
\end{tabular}




\section{Crystallinity}

The differences in the crystallinity of skeletal apatite are observable by comparing the XRD patterns for different taxa (Fig. 3). According to these XRD patterns, the studied apatites can be subdivided into two groups. One group comprises the apatites in ray and teleost scales, comparable to the apatite in mammal bones. The other group includes the apatites in shark scales, resembling in crystallinity the apatite in human tooth. Unlike teleost scales, the shark scales (and a human tooth) show a specific shape of XRD reflections, close to [hk0] direction of the apatite lattice.

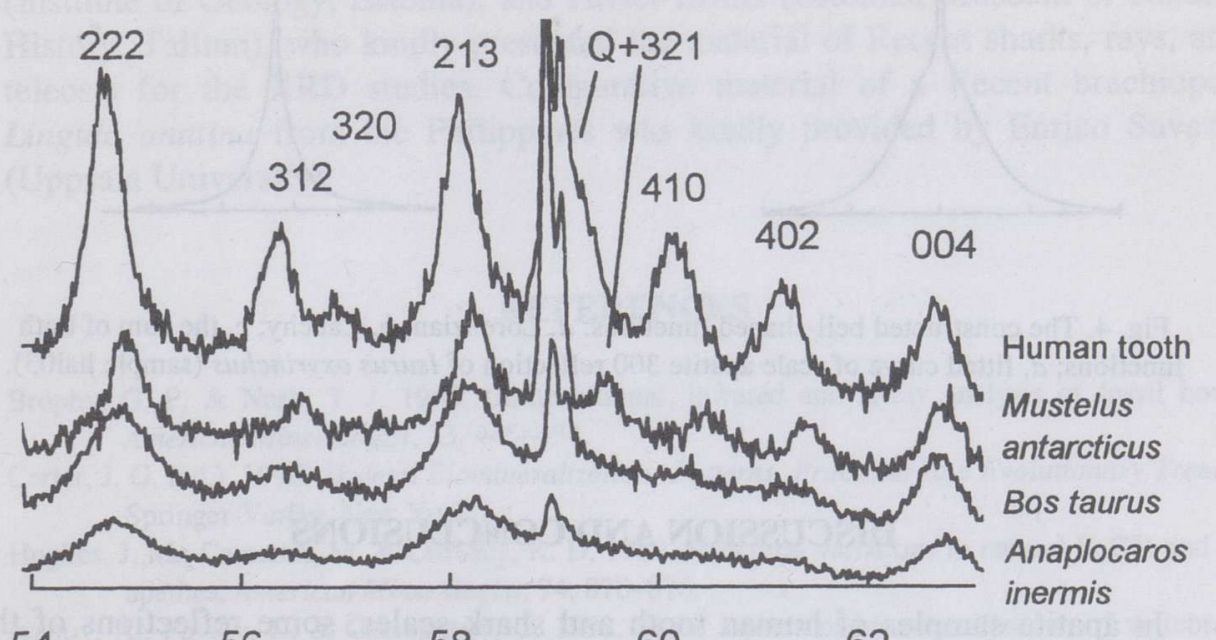

54 56

58

60

62

Angle of diffraction, deg. $2 \Theta$

Fig. 3. XRD patterns of selected samples.

Theoretically, the reflection profiles could approximate two extreme functions: Lorenzian (in case of high uniformity of crystallite dimensions in a particular lattice direction) or Cauchy (in case of a wide range of crystallite dimensions). Figure 4 shows the shape of constructed Lorenzian (Fig. 4a) and Cauchy (Fig. 4b) functions, and their combination, as compared to an original peak profile of apatite from shark scales. For the natural samples, we used the combination of the two functions. Figure $4 c$ illustrates a sample, where apatite is represented by a mixture of smaller, unisized, and larger crystallites of wider size and proportion range. For apatite from shark scales and a human tooth, the best fitting function was the combination of derivations of Lorenzian and Cauchy profiles (Fig. 4d). 

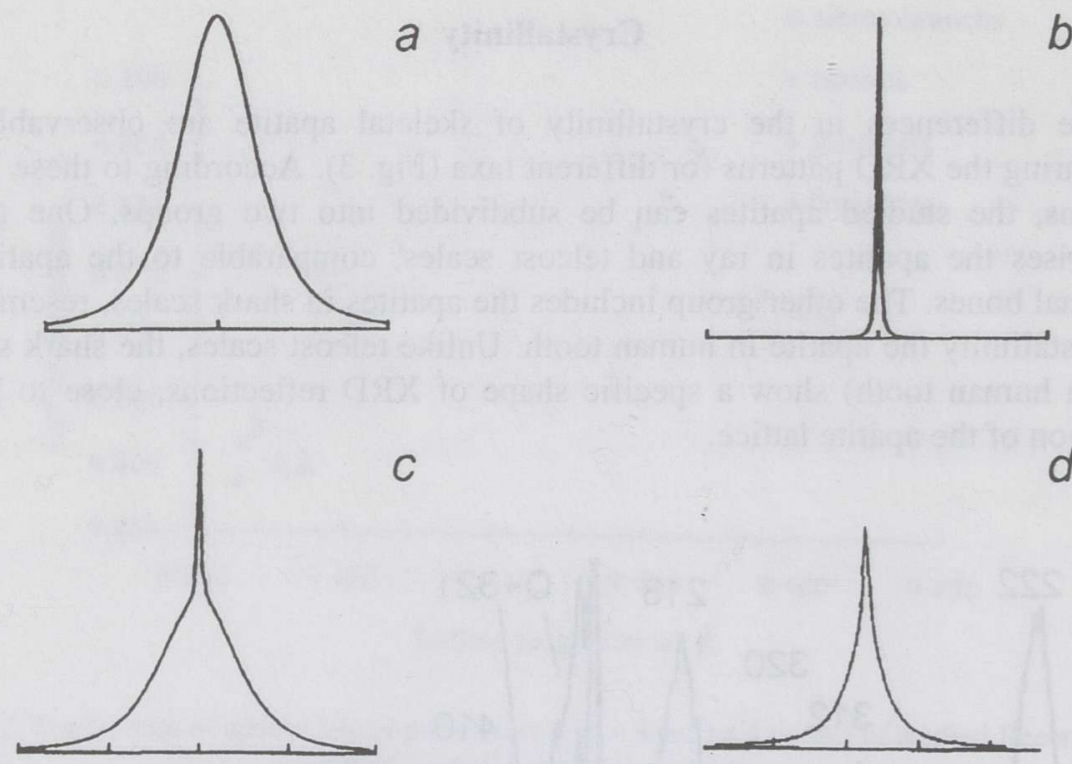

C

$d$

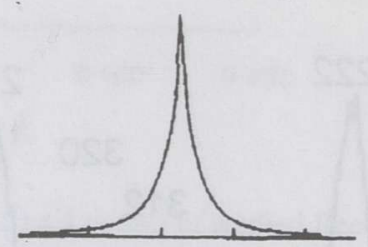

Fig. 4. The constructed bell-shaped functions: $a$, Lorenzian; $b$, Cauchy; $c$, the sum of both functions; $d$, fitted curve of scale apatite 300 reflection of Isurus oxyrinchus (sample hai03).

\section{DISCUSSION AND CONCLUSIONS}

In apatite samples of human tooth and shark scales, some reflections of the lattice direction [hk0] can be described with the sum of two bell-shaped functions (see Fig. 4). These kind of samples consist of a mixture of two types of crystallites. In case of vertebrate bones, scales of bony fishes and lingulate brachiopod shells the apatite is built up of prismatic crystallites having monotonous cross dimensions $\sim 80 \AA$ and $\sim 200 \AA$, respectively, while the human tooth and shark scales consist of two apatite crystal types with average dimensions of $100-500 \AA$ and up to $1000 \AA$, respectively. In the cross lattice direction, [001] (direction of hexagonal prism), the crystallite dimensions are significantly less variable and can be estimated as thousands of angstroms.

Comparison of the lattice parameters (Table 2; Fig. 2) indicates that apatite varieties in lingulate brachiopod shells and vertebrate hard tissues differ significantly. A higher lattice parameter $a$ in vertebrates corresponds to a higher content of $\mathrm{OH}$ anion. It is notable that the shark scales contain significantly less hydroxyl than other fish scales and vertebrate skeletal tissues, and appear to be closer in composition to the lingulate brachiopods. Assuming that infraspecific and ontogenetic variation of apatite mineralogy is somewhat limited, these data suggest that vertebrate hard tissues have taxon-specific apatite composition. 
According to most previous studies on apatite composition in fossil skeletal fragments, the teeth and bones of Recent vertebrates are suitable comparative material for evaluating the influence of taphonomic processes. However, our results suggest that Recent shark scales may provide a closer approximation to the initial composition of early vertebrate dermal sclerites.

\section{ACKNOWLEDGEMENTS}

This study was supported by Estonian Science Foundation grants No. 1663 and 2723. We thank Peter Pridmore (Australian National University), Elga Kurik (Institute of Geology, Estonia), and Peeter Ernits (Estonian Museum of Natural History, Tallinn), who kindly presented the material of Recent sharks, rays, and teleosts for the XRD studies. Comparative material of a Recent brachiopod Lingula anatina from the Philippines was kindly provided by Enrico Savazzi (Uppsala University).

\section{REFERENCES}

Brophy, G. P. \& Nash, T. J. 1968. Compositional, infrared and X-ray analysis of fossil bone. American Mineralogist, 53, 445-454.

Carter, J. G. (ed.). 1990. Skeletal Biomineralization: Patterns, Processes and Evolutionary Trends. Springer-Verlag, New York.

Hughes, J. M., Cameron, M. \& Crowley, K. D. 1989. Structural variations in natural F, OH and Cl apatites. American Mineralogist, 74, 870-876.

Ivanov, A., Pavlov, D. \& Cherepanov, G. 1992. Some aspects of biomineralization of vertebrate exoskeleton. In Fossil Fishes as Living Animals (Mark-Kurik, E., ed.). Estonian Academy of Sciences, Tallinn, 159-165.

LeGeros, R. Z., Pan, C.-M., Suga, S. \& Watabe, N. 1985. Crystallo-chemical properties of apatite in Atremate brachiopod shells. Calcif. Tissue Int., 37, 98-100.

Lowenstam, H. A. \& Weiner, S. 1992. Phosphatic shell plate of the barnacle Ibla (Cirripedia): A bone-like structure. Proc. Nat. Acad. Sci. USA, 89, 10 573-10 577.

McConnell, D. 1973. Apatite - its Crystal Chemistry, Mineralogy, Utilization, and Geologic and Biologic occurrences. Springer-Verlag, Wien.

Miller, A. 1984. Collagen: the organic matrix of bone. Philos. Trans. R. Soc. Lond. B., 304, $455-477$.

Nathan, Y. 1984. The mineralogy and geochemistry of phosphorites. In Phosphate Minerals (Nriagu, J. O. \& Moore, P. B., eds). Springer-Verlag, Berlin, 275-291.

Nemliher, J., Laas, T., Kallaste, T. \& Puura, I. 1996. Mineral composition of the dermal skeleton of Devonian fishes from Estonia. Proc. Estonian Acad. Sci. Geol., 45, 4, 203-215.

Nemliher, J. \& Puura, I. 1996. Shell mineralogy of lingulate brachiopods from the East Baltic Cambrian-Ordovician "Obolus-phosphorite". In WOGOGOB-94 Symposium (Stouge, S., ed.). Denmarks og Grønlands Geologiske Undersøgelse. Rapport 1996, 98, 83-91.

Watabe, N. 1990. Calcium phosphate structures in invertebrates and protozoans. In Skeletal Biomineralization: Patterns, Processes and Evolutionary Trends (Carter, J. G., ed.). Springer-Verlag, New York, 35-44. 


\title{
HÜDROKSÜAPATIIDI ERIMID RETSENTSETE KALADE SOOMUSTES
}

Jüri NEMLIHER, Toivo KALLASTE ja Ivar PUURA

Röntgenstruktuuranalüüsiga on uuritud apatiidi mineraloogiat retsentsete haide, raide ja teleostide soomustes. Kõik vaadeldud soomused koosnesid mõnevõrra erinevate võreparameetritega hüdroksüülapatiidist. Retsentsete raide ja teleostide soomustes sisalduva apatiidi võreparameetrid on vahemikus $a=9,44-9,46 \AA$ ja $c=6,87-6,88 \AA$, mis on võrreldav retsentsete vertebraatide kontides sisalduva apatiidi omadega. Haisoomustes sisalduva apatiidi võreparameetrid - $a=9,40-9,41 \AA$ ja $c=6,87-6,88 \AA$ - on lähedased retsentsete lingulaatide kodade apatiidi omadele. Võreparameetrite varieeruvus peegeldab apatiidi keemilise koostise erinevust, eelkõige hüdroksüüliooni, fluori ja karbonaatiooni sisalduses. Retsentsete kalade kõrgtaksonite soomuste apatiidi koostis on huvipakkuv evolutsiooni kontekstis ning oluline fossiilsete vertebraatide skeleti mineraloogia tõlgendamisel.

\section{РАЗНОВИДНОСТИ ГИДРОКСИЛАПАТИТА В ЧЕШУЕ СОВРЕМЕННЫХ РЫБ}

\author{
Юри НЕМЛИХЕР, Тойво КАЛЛАСТЕ и Ивар ПУУРА
}

С помощью рентгеноструктурного анализа исследованы чешуи современных акул, скатов и костных рыб. Все чешуи состоят из гидроксилапатита с различными параметрами кристаллической решетки. Апатит чешуй современных скатов и костных рыб (параметры кристаллической решетки в пределах $a=9,44-9,46 \AA$ и $c=6,87-6,88 \AA$ ) сопоставим с костным апатитом современных позвоночных, а апатит чешуй современных акул ( $a=9,40-9,41 \AA$ и $c=6,87-6,88 \AA)$ более схож с апатитом створок современных лингулат. Различия в свойствах апатита чешуй современных рыб представляют интерес в эволюционном аспекте и существенны для интерпретации минерального состава твердых тканей ископаемых позвоночных. 